\title{
1 Corinthians 7:17-24. Identity and human dignity amidst power and liminality
}

\author{
Author: \\ Jeremy Punt ${ }^{1}$ \\ Affiliation: \\ ${ }^{1}$ Department of Old and New \\ Testament, University of \\ Stellenbosch, South Africa \\ Correspondence to: \\ Jeremy Punt \\ Email: \\ jpunt@sun.ac.za \\ Postal address: \\ Faculty of Theology, 171 \\ Dorp Street, Stellenbosch \\ 7600 , South Africa

\section{Dates:} \\ Received: 22 Sept. 2011 \\ Accepted: 25 Jan. 2012 \\ Published: 19 Apr. 2012 \\ How to cite this article: \\ Punt, J., 2012, '1 Corinthians \\ 7:17-24. Identity and human \\ dignity amidst power and \\ liminality', Verbum et Ecclesia \\ 33(1), Art. \#683, 9 pages. \\ http://dx.doi.org/10.4102/ \\ ve.v33i1.683 \\ Note: \\ An edited version of this \\ paper was read at the SBL \\ Annual Meeting (Contextual \\ Bible Interpretation), \\ November 2010, Atlanta GA, \\ USA. Financial assistance \\ from the NRF to attend \\ the meeting is gratefully \\ acknowledged.
}

C) 2012. The Authors. Licensee: AOSIS OpenJournals. This work is licensed under the Creative Commons Attribution License.
Paul's concern with identity, and in particular the identity of the believer in relation to Jesus Christ, is an important concern in his writings. In the midst of an important section dedicated to advice and instruction on marriage in his first letter to the Corinthians, Paul encouraged his audience in 1 Corinthians 7:17-24 to remain in the calling by, or position in, which they were called. Concerning these circumstances he refers to circumcision (1 Cor 7:18-19) and slavery (1 Cor 7:21-23) by name. These Pauline instructions are investigated against the backdrop of both the 1st century CE context and post-apartheid South Africa, where issues of identity and marginality rub shoulders with claims to ownership and entitlement, on the one hand, and issues of human dignity, on the other.

\section{Introduction}

\section{Life-context in which interpretation takes place}

The 27th of April 1994 was the historical moment when South Africa formally changed from a minority-ruled apartheid-state into the modern democratic New South Africa, installing the iconic Nelson Mandela as the first democratically elected Black president of South Africa. It was a day set against a long, troublesome and mostly turbulent few decades, which should also be understood within the framework of centuries of colonial rule of one form or another. On this day, the country at the southern tip of the African continent comprising a 'rainbow people', to use Desmond Tutu's famous phrase, of indigenous people such as the Khoisan, southern moving tribes from further north on the continent, and initially Dutch and later British, French, German and other settlers, evolved into another phase of socio-political development.

The former Dutch settlement that begun in 1652 and was reshaped into a British colony (1806) and later became an apartheid-state (1948) had its democratic awakening in 1994. It saw the country move into a post-liberation democratic dispensation that has brought about many changes, of which the transfer of power from a White minority to a Black majority was the most telling, but not necessarily the most decisive, moment. Facing many problems of various kinds, the new dispensation in South Africa has, thus far, not brought about the expected significant improvement to the lives of the majority of its citizens in the country, whilst, at the same time, the new dispensation has developed more of a global profile for itself. Its attempts to enhance the country's profile, especially at an economic level, often further complicate an already complex situation, such as communities differentiated by social, cultural, political and economical differences. Political and other leaders also attempt, in varying ways and degrees, to deal with an increasingly technology-based economy in the information era. Additionally these contribute to what can be described in many ways as a postcolonial setting. Interestingly, the role of organised religion and Christian groups in particular, often with strong appeals made from the Bible, were important and influential factors both in providing justification for, as well as in combating, the apartheid regime. Whilst the participation of religious groups and figures in post-apartheid South Africa, thus far, has been of a different nature and complexion, ${ }^{1}$ the link between religion and politics has evidently not been severed ${ }^{2}$ (cf. Punt 2007; 2009).

In keeping with the parameters of the Contextual Bible Interpretation group, ${ }^{3}$ the context of South Africa today serves as the interpretative canvas for 1 Corinthians 7:17-24. Rather than a literary or historically-focussed exegesis, ${ }^{4}$ overtly or otherwise oblivious of any real-life,

1.In the words of emeritus-archbishop Desmond Tutu, 'now the church can go back to being church'. These are words he has been reproached for speaking by many, as they are taken to suggest a withdrawal of organised religion from the public sphere, and even hint at the privatisation of religion.

2.This is indicated by ongoing cordial although not necessary amicable relations between national and local government and church leaders and groups in South Africa, including meetings and forums held between religious leaders and government, and even calls by government for the church to assist in 'moral regeneration'.

3.This is a programme unit of the Society of Biblical Literature intent on exploring the contextual reading and interpretation of biblical texts in various contemporary contexts.

4.The bibliography refers to a number of detailed studies, variously focussed. A few caveats are appropriate, for partial or no discussion of matters important in the exegesis of this text. For a more complete overview of previous interpretations of 1 Corinthians 7 ; the structure of the passage and its fit into 1 Corinthians, see Braxton (2000:9-34) and Kim (2008:76-77) 
flesh-and-blood context, my reading here takes life in the contemporary South Africa context into account, marked as it is by power and liminality as a primary interlocutor. It is an explicit contextual interpretation of the text, ${ }^{5}$ and in the next section a rudimentary thumbnail sketch of the South African context follows.

\section{The new South Africa and its challenges}

Apartheid's social engineering, with its political disenfranchisement, creation of structural disadvantages and imposition of socio-economic control and distortions, probably hit South African people hardest at their most vulnerable level, in destroying human dignity through the colonisation of the mind (Ngugi 1986) and establishing a coloniality of being (Mignolo 2007). ${ }^{6}$ Firstly, communities and individuals may still be suffering from a serious lack of selfesteem and self-confidence, and might yet not have acquired even very basic life skills, all of which are not unrelated to the surrounding moral landscape. Much of this has naturally filtered through into communities where a breakdown of relationships is characterised by broken families and family structures, rampant teenage pregnancies, high levels of HIV infections and AIDS, pervasive substance abuse, unacceptable levels of corruption in the business and civil sectors, widespread criminality and violent crimes such as murder, rape and assault, amongst other crimes. The strategy of making the land ungovernable as part of the liberation movements' struggle against apartheid grew into a popular groundswell which has, to date, proved difficult to turn around in full, even though the erstwhile liberation movements are now, for the largest part, represented in political parties and in government. The strong claims about, and appeals upon, human dignity, enshrined in the new South African Constitution and Bill of Human Rights, are yet to become part of its social fabric. ${ }^{7}$

Secondly, the quest for identity in an increasingly multicultural country, continent and world may appear a fool's errand, but this is a pronounced pursuit in South African society. Tensions were evident for example in recent public debates about the ox-slaughtering ceremonies for the recent Soccer World Cup tournament. Controversy surrounded the ceremonial killing of an ox by Xhosa warrior Zakhele Sigcawu on Tuesday 24 May 2010 in preparation for, and securing of, ancestral blessings for the Soccer City stadium in Johannesburg, and the tournament that was to follow (Sport24 2010). Ongoing discussions of the polygamy of state president Jacob Zuma are at least as vibrant as

5.This is not, in any way, stated apologetically: as much as biblical reading, biblical scholarship is always socially located, and is carried out by readers with particular gender, cultural, social and other identities, and requires the rejection of the Enlightenment tradition's 'attempt to erase the identity of the reader by means of the rhetoric of reason and objectivity' and its derivative, the belief that Western biblica critics can justifiably speak on behalf of all other readers (Brett 1998:305).

6.Discursive colonialism is often more pervasive and enduring if less tangible than historical colonialism, 'a colonization of the mind and the soul, a rendering of the whole nowhere as strongly as on human worth and dignity, and the value of human lives.

7.The consistent resurgence of human indignity and accompanying claims, during South Africa's apartheid years, were met by the government's blatant denial of and restrictions on human dignity. those about manifestations of White Afrikaner nationalism, whether or not these are about culture and its assertion or subterfuges for (respectively) legitimating a certain lifestyle, or clinging to privileges reminiscent of apartheid times.

Thirdly, South Africa is challenged today to deal with inequalities of its recent and more distant past, including desperate poverty (to the extent of children dying from hunger and terrible infant mortality rates, to name a few), and disease (vast numbers of people infected with HIV and AIDS, high incidences of tuberculosis infections and malaria deaths). These occur amidst regular reports of national and local government representatives and employees' involvement in distortion, corruption or both. ${ }^{8}$ South African citizens are deprived not only of their legitimate claim upon resources but must observe public officials squandering such resources on exorbitant yet fleeting materialist tokens of wealth and prosperity. ${ }^{9}$ Authorities have started to admit that the country suffers from a serious problem with violent crime, and is often dubbed the murder and rape capital of the world, with little respect for human life amidst what has become almost nostalgic invocations of an Ubuntu-based concern for others. It may have become a cliché to refer to crime-ridden South African, but its effects on society are, if anything, increasing: violent crime is surging and white-collar crime is fast becoming another scourge.

Fourthly, in South Africa race and gender remain major dividing lines. Major problems in the country are related to what is often called a race 'fault line' that both defines and divides the people of South Africa at many different levels. Deep-seated ethnic differences and conflicts brewing under the surface add to a climate susceptible to polarisation. ${ }^{10}$ Serious gender and sexuality concerns exist amidst claims to traditional culture, proclaimed as sacrosanct, in a very dominant patriarchal context, which is strongly heteronormative and largely homophobic. Such factors work hand in hand with over-simplified but popular notions of majority and minority politics, of (Black) political versus (White) economic power, of the (re)distribution of arable agricultural lands and mineral prospecting rights, of affirmative action as the initiative of the (Black) majority aimed at the (White) minority, with relentless energy.

Attempts to read 1 Corinthians 7:17-24 as suggesting that people primarily should make the best of their particular life situations (cf. Thiselton 2006:110-111), conjure up notions of securing privilege for some people whilst placating

8.An important, but certainly not singular, example is the ongoing saga of South Africa's Arms Deal, a multi-billion rand venture in which some of the country's highest ranking politicians and leaders are implicated.

9.Such practices have given rise to neologisms in South Africa, which would have been funny if the impact of what they refer to was not so serious, such as 'tenderpreneurs' which refers to those who manipulate government tender processes, from the inside and the outside, through corruption to enrich themselves, 'fat cats' riding on the 'gravy train' refers to local representatives in different levels of government intent on enriching themselves at the cost of the general population.

10.The question of the origin of such ethnic differences or claims in this regard should be left aside for the moment, and without discounting the role of colonial authorities over many decades, or that of the apartheid government in both constructing and appealing to such differences and violence emanating from it for political expediency, ethnicity is considered important from both emic and etic perspectives in South Africa. 
marginalised people. This is particularly true in the context of hardships and injustice, in the absence of apparent concern for addressing structural inequities and systemic injustices, in a situation perceived to be skewed and favouring the powerful and privileged. With the tension between the South African context characterised by different power constellations and varying manifestations and degrees of liminality, the interpretation of 1 Corinthians 7:17-24, which follows, will be not only contextualise but also relate to issues of identity and human dignity in particular. A few words on the context and setting of the first Corinthian letter are appropriate at this stage.

\section{Analysis of the text The overall presentation of 1 Corinthians}

Shortly after Paul left Corinth, around 51 CE, he apparently established himself in Ephesus in Asia Minor. This city was probably his pastoral and missional basis from $52 \mathrm{CE}$ to 54 $\mathrm{CE}$ and it was from here that he visited churches in Galatia, Antioch and elsewhere. In response to receiving disturbing news about the Jesus-followers in Corinth in 53 or early 54 $\mathrm{CE}$, he wrote the first letter to the Corinthian congregation (cf. 1 Cor 5:9). When Chloe's people (1 Cor 7:11), shortly thereafter, reported to Paul about tension and ructions in the congregation, Paul received a letter from the Corinthian community (1 Cor 7:1). This contained questions about marriage and celibacy, meat offered to idols, gifts of the Spirit, and other matters. In his reply he wrote what is today known to us as the first letter to the Corinthians. In 1 Corinthians 7:1-40 Paul responded to questions about marriage, and 1 Corinthians 7:17-24 expands on the notion of receiving and living the calling of God amidst certain circumstances. ${ }^{11}$

Corinth was an important city in New Testament times because its location, on the Corinthian isthmus, made it a strategic city for military, as well as trade and economic reasons. ${ }^{12}$ After Corinth became involved in the political issues of Sparta and Rome, the city was destroyed in 146 BCE by the Romans, but was re-established in 44 BCE as a Roman colony (Colonia Laus Julia Corinthiensis) in honour of Julius Caesar, who was murdered in the same year. Although the rebuilt city was inhabited initially by retired Roman soldiers, Roman freedmen and women, Roman slaves, traders and business people from elsewhere soon made Corinth their home. Corinth had a cosmopolitan and international makeup and fell under firm Roman control, with access to crucial trade routes, and with sufficient natural resources for manufacturing and a blooming business culture. Corinth was a world-class city like few others in the first century CE. Competition, patronage and what today would be called a consumerist culture and a focus on success in various ways, were important elements of life in this city.

11.1 Corinthians 7:17-24 is not viewed here as a digression, but rather as an integral part of the argument in 1 Corinthians 7 (cf. Braxton 2000:55-56, contra Bartchy 1973: esp 158; Dawes 1990:681-697). For the structure of 1 Corinthians 7, see 1973: esp 158; Dawes 1990:681-697). For
Braxton (2000:9-34) and Kim (2008:76-77).

12.With two harbours, Lechaeum to the northwest of the Gulf of Corinth and Cenchrae in the Saronic Gulf of the Aegean Sea, Corinth was a true port city and a vital connection point between North-South and East-West trade routes.
The primary socio-historical setting that Paul's first letter to the Corinthians addressed has remained a matter of dispute. The traditional position holds that he challenged the realised eschatological framework that prevailed in the Corinthian church, which gave rise to worldly contentment. In biblical scholarship an important consensus is forming that the base of the tensions in the community in Corinth was less theological than it should have been (narrowly conceived) and was more sociological, and was, in fact, about problems arising from socio-economic divisions (cf. Martin 1995). Paul's challenge to an ideology of privilege in 1 Corinthians also countered the tensions between the more numerous but lower-status 'charter members', and the more recent converts, who were fewer in number, but whose wealth, power and status has unsettled the standards and expectations within the community (Elliott 1994:204-214; Meeks 1983:117-118; Theissen 1983:106-110). Paul's first Corinthian letter most likely addressed problems that were brought about by social stratification in the communities.

\section{Commentary on selected themes}

The first letter to the Corinthians engaged the social reality of the early Jesus follower-community in Corinth on a wide front. This addressed, in Chapter 7, some specific and primary socio-cultural and economic structures and configurations. In 1 Corinthians Paul is focussing on marriage, but in the middle of the chapter he also addresses two other important aspects related to the social make-up of the community. Firstly, there was the ubiquitous system of slavery, and secondly, there was the connection with Paul's broader socio-cultural point of reference, Jew-Gentile relationships. The social situation, and its links and connections in 1 Corinthians 7:17-24, makes for a complex argument, ${ }^{13}$ as demonstrated by the past range of interpretations of this passage.

The 1 Corinthians 7:17-24 text has, in the past, often received negative press, and has been understood through the lens of a specific translation and interpretation of 1 Corinthians $7: 20$. This intention was to encourage and emphasise the socio-cultural status quo, insisting on its maintenance. At times this line of interpretation was described even as Paul's theory of the status quo (Schweitzer 1968:187-194). ${ }^{14}$ However, rather than a Pauline insistence to stay in a certain state or social position, the focus of this passage is probably more on the implications of the calling of God and serving Christ within particular contexts or situations. 'The key point is ... that Christians can fully serve Christ as Lord in whatever situation they find themselves' (Thiselton 2006:111, emphasis in the original). However, in such readings the criteria to determine the 'key point' may be too strongly biased towards a theological perspective, oblivious to social location-

13.The different scholarly reactions to this passage underline its complexity, with wire (1990:72-97), for example, seeing this passage as Paul's attempt to restrict the emancipatory energies of holy women in Corinth, and the concessions functioning as leverage to ensure women move back into conventional, patriarchal marriage structures and associated roles. Braxton (2000) believes 1 Corinthians 7:17-24 to be an example of deliberate ambiguity on Paul's part resulting from his inability or unwillingness to provide comprehensive and exhaustive final answers regarding
celibacy, marriage, divorce and remarriage.

14.Paul's theory or even theology of the status quo meant '[i]f, therefore, a slave became a believer he [sic] should not, on this theory, if he were afterwards offered freedom, accept it' (Schweitzer 1968:194-195). 
determinants, and driving an unwarranted disjuncture between theological obedience and social responsibility.

Another range of interpretive positions on 1 Corinthians 7:17-24 claims more social engagement for Paul's words. In the recent past the text has received, at least in some quarters, positive acclamation, viewing it as Paul's encouragement for slaves to avail themselves of freedom should it come their way. ${ }^{15}$ This was a realistic possibility in first century slavery, in contrast to its later colonialist variant! Earlier readings of 1 Corinthians 7:17-24, which ascribed a social conservative position to Paul, have been challenged by scholars who argue that Paul tried to overcome the basic socio-economic power relations which governed people's lives under the Roman Empire (e.g. Horsley 1998:100). The charge of socio-political quietism levelled against Paul, that is based on this passage, is challenged by arguments that the rule in 1 Corinthians 7:17-24 is not a rule of the status quo, but that the focus of remaining in the calling is a call to peace. This is along the same lines as the appeal that discourages the believer to dispute divorce from an unbelieving spouse (1 Cor 7:15), and that it does not bind individual followers of Jesus to a particular social status (Elliott 1994:211-214).

A contextual reading of 1 Corinthians 7:17-24, that exposed the marginalised status of people, could possibly be read also as theological legitimation for differentiating social structures, in contexts like South Africa, where power and liminality concerns are crucial. In this contextual reading, at least the following three concerns require some discussion.

\section{$\kappa \lambda \tilde{\eta} \sigma \iota \varsigma$ as divine assignment or social position?}

Emancipatory or socially challenging readings of 1 Corinthians 7 hinge, of course, on the interpretation of $\kappa \lambda \tilde{\eta} \sigma \iota \varsigma$ [calling] and related terminology, and in particular on the insistence that someone's calling was not the same as the person's standing in society. For Paul social location was not a matter of indifference, but given that God's calling, to put it theologically, is a calling to holiness, it brings the person into the sphere of God's lordship, and, thus, liberation. From 1 Corinthians 7 it is clear that Paul perceived the call of God as a divine action, bestowing apostolic authority on him and bringing about a different perspective and ethos for Jesusfollowers. This created a community with a different ethos and centred on Christ.

The call or calling topos is important in 1 Corinthians, particularly in the first and seventh chapters. In this context Paul is already identified in 1 Corinthians 1:1 as the $\kappa \lambda \eta \tau$ ó $\varsigma$ [called] apostle, and the Corinthian community as $\kappa \lambda \eta \tau$ ○ [called] saints in 1 Corinthians 1:2. ${ }^{16}$ The result is that the elite

15.Manumission was not only a possibility for many if not the majority of slaves in the 1st century, but it was also such mediating aspects of slavery that perpetuated this system. Caution is, therefore, advised for references to manumission serving as attempts to portray a system with more tolerable conditions for slaves at the because slavery was employed as a theological metaphor by Paul.

16.For further occurrences of $\kappa \alpha \lambda \dot{\varepsilon} \omega / \kappa \lambda \tilde{\eta} \sigma ı \varsigma$ in this sense of calling from God, see cf. 1 Corinthians 1:9, 24, 26 besides 1 Corinthians 7:15,17, 18, 21 (in 1 Cor 10:27 Ka $\lambda \dot{\varepsilon} \omega$ is used with the meaning of 'invite'). For the notion of a philosopher responding to the divine call in Cynic philosophy, cf. the Stoic philosopher Epictetus, Discourses 3.22.23; cf. Braxton (2000:43, n94) amongst them were prevented from identifying superiority in relation to powerless as a sign of God's preference, and duly that whilst the 'educated, powerful and well-born' (1 Cor 1:26) were found in the congregation, their presence would not define it. On the contrary, the presence of the powerless, the nobodies (1 Cor 1:27-28), was a sign of God's calling, because the bodies of the powerless were holy, even if their labour belonged to others within the structures of society. According to Elliott (1994:214) this did not mean that Paul acquiesced to the imbalances of power and privilege within that society, but rather that the bodies of the poor were holy but not yet free, although their holiness was a guarantee of coming freedom ( $R m$ 8:9-17). The notion of the calling of God would have impacted strongly on a context characterised by ethnic tension, and the disparate social status of members of the community (Braxton 2000:71-105). Calling cannot be read as equivalent to a social position, and this is also because Paul's point and reference is, in every specific case, someone who receives the calling in a particular setting, and as such they are called as circumcised or uncircumcised (1 Cor 7:18), or called as a slave (1 Cor 7:21).

In Paul's letters circumcision and uncircumcision refer to ethnic distinctions, even if ethnic credentials were not required for inclusion in early Jesusfollower communities. ${ }^{17}$ Non-Jews were received into the movement without requiring ethnic credentials and apart from belief in one creator God, many other fundamental axioms of Judaism, such as covenantal nomism, were abandoned to accommodate non-Jewish believers (Runesson 2008). However, early Jesus follower texts regularly invoked racial and ethnic categories, ${ }^{18}$ contrary to scholarly opinion. ${ }^{19}$ The early followers of Jesus used racial stereotyping 'to denounce Christian rivals as barbarians and Jews' (Buell 2001:473) in the 1st century Greco-Roman world, where kinship and ethnicity were expressed with a variety of different terms.$^{20}$ Regardless of their link to birth and descent, terms were used interchangeably to signify a different understanding of race and ethnicity. These terms were often closely associated with religious practice, but as mutable terms that did not presuppose 'essences' ${ }^{21}$. They could,

17. Ethnicity is a cultural construct and a matter of self-ascription, and is a constructed notion drafted from the inside, intent on scripting borders for the group complete with necessary protection (cf. Braxton 2000:72-93; Campbell 2008:3-5).

18. Historical constructions of early Christianity often tend to assume that the notion of Christian identity excluded any racial connotations, perhaps as a result of the ascendency of scientific racism in the late-19th century. Buell (2001:449-76) investigated authors from the time of early Christianity, including Christian authors such as Diogenes, Clement of Alexandria, Athenagoras, Justin Martyr, and Origin, but also a wider array of ancient authors of a wider temporal spectrum. These included authros such as Philo of Alexandria, Isocrates, Dionysius of Halicarnassus, included authror include Matthew 21:43 (genos), John 1:46 (Nazareth), 1 Corinathians 7:52 (Galileans), 1 Peter 2:9-10
(genos, ethnos, laos), and others.

19.Some scholars insist on the perceived universality of early Christian thought as authoritative ideology, others, from the margin, emphasise the apparent inclusive nature of early Christianity, as embracing the vulnerable. Both sets of scholars share the modern opinion of race as biological, identity as natural and the conviction that early Christian thought detaches itself from racial or ethnic categories. Together with erasure, silencing and marginalisation, universality can be an ideological strategy in racialised thinking, intent on reinforcing the Euro-American perspective, cf. Kelley (2002:213-219, espec. 214).

20.Genos, ethnos, laos, and phylos can all be translated interchangeably with terms such as 'people', 'race' and 'ethnicity', although some other uses for these words are identified (Buell 2001:456-457 n20).

21.'Early Christians inhabited a world in which many facets of one's self, including race or ethnicity, were perceived as mutable - sex, status, citizenship, and even humanness', so that 'boundaries between animals, humans, and gods, those between slave and free, and those between male and female were all seen to be between slave and free, and those between male and female were all seen to be
breachable'. Rather than understanding race or ethnicity as givens, early Christians used these concepts when speaking of conversion (Buell 2001:466-467; 467, n50). 
therefore, accommodate both changes between and ranking of ethnicities, tolerate both an insistence of ethnic particularity and a universal ideal, ${ }^{22}$ and allow Christian conversion to be expressed in ethnic terms (Buell 2011:469, 473). 'Race' and 'ethnicity' were terms that, therefore, inevitably were involved in identity negotiation in communities of Jesus followers. ${ }^{23}$

Slavery was a social position that knew multiple forms in the 1 st century CE, as it was neither restricted to nor constituted a social class or status. Slaves' lives, however, were determined by their owners and their whims..$^{24}$ Slavery was generally not a desired state of being, ${ }^{25}$ and where it became a necessity it was tolerable, given the prospect of its eventual cessation, which still left the former slave in the position of a freed person. This mostly resulted in his or her dependence upon the former owner turned patron, with limited claim to social position and the privileges available to (especially male) free persons. ${ }^{26}$ Slavery as an institution was maintained by the threat and use of violence, including punishment, torture and even execution (Osiek 2005:206). First century patronage stands juxtaposed to slavery as an entire network of patron obligations, which regulated perceptions of the world whilst also regulating the activities of communities and individuals. It was particularly important in securing the dominance of imperial culture and its societal workings, ${ }^{27}$ with household ethics and patronage understood as sanctioned by the gods. ${ }^{28}$ Paul's constructions, in 1 Corinthians 3:23 (cf. 1 Cor 3:5-6), exemplify patronage relations. These are found where the relationship between the Corinthians and God was seen as mediated by Christ, and in 1 Corinthians 4:14-15 where

22.Christian universalism was at times expressed in ethnic terms (cf. 1 Pt 2:9-10) demonstrating that it was less about the incorporation of other ethnicities into an agglomeration where such distinctions were unimportant, than about other ethnicities co-constituting a new race or ethnicity. It was more about enlisting for a new identity than being included in non-ethnic or race-less obliqueness (cf. Buell 2001:473).

23.Early Christians found race and ethnicity useful for self-definition against outsiders, as 'central organizing concepts for Christianness' as well as for authorising specific forms of Christian conviction and practice as universal norm. This was also used against other insiders, in competition with rival groups and in asserting a particular form of Christian identity (Buell 2001:451).

24.Although some slaves may have had a low status, they could have had a disproportionately high class indication by being the slave-agent of a high-status person. Claiming to be someone's slave then turned into a claim to prestige rather than an act of humility(cf. Martin ([1990]; Osiek [2005:209]).

25.For early ambivalence, see Epictetus, Discourses 4.1: 'The slave wishes to be set free immediately...'If I shall be set free, immediately it is all happiness, I care for no man, I speak to all as an equal and, like to them, I go where I choose, I come from any place I choose, and go where I choose.' Then he is set free; and forthwith having no place where he can eat, he looks for some man to flatter, some on with whom he shall sup: then he either works with his body and endures the most dreafful things; and if he can obtain a manger, he falls into a slavery much worse dreadful things; and if he can obtain a manger, he falls into a slavery much worse than his former slavery; or even if he is become rich, being a man without any and desires to be a slave again'.

26. And in all of these discussions it is important to distinguish between various socia locations, two of which are important to keep in mind here. Roman slavery and Greek or Eastern slavery show some differences between each other, and, this is found with rural slaves and especially slaves in the mines, who were exposed to vastly different circumstances than household slaves in the cities (cf. Briggs 2000:111-112).

27.The materiality of Roman social practices was the external manifestation of an intangible morality (for example the patronage practices within the traditional sanctity of the household) that offered a holistic perception of the world in which Roman religion and society were intimately connected.

28. As far as the Roman Empire was concerned, the social order and the divine order were one and the same, and, therefore, the ethics of Roman society were sacred and non-negotiable. '[T]he Romans always understood themselves to be the world's rightfully dominant culture, the gods' own people, and they understood the workings of their society, the ethics of household and of patronage, to be the workings of their society, the
sacred' (Hollingshead 1998:113).
Paul as spiritual 'father' mediated between the Corinthians 'children' and being in Christ.

For Paul, the pervasive and far-reaching effect of God's calling was to unsettle privilege and bestow (new) value on those in marginalised positions, whose lives were regulated by ethnic connotations or social position, such as the distinction between Jews and others, or slavery. The focus on the calling is clear in 1 Corinthians 7:20, where the emphasis is to remain in the calling ( $\dot{\varepsilon} v \tau \tilde{\eta} \kappa \lambda \eta \dot{\sigma} \sigma \varepsilon)$ in which someone was called ( $\dot{\kappa} \kappa \lambda \dot{\eta} \theta \eta)$. However, whilst it can be agreed that $\kappa \lambda \tilde{\eta} \sigma 1 \varsigma$ should be understood here as calling, and should not be equated to social position, the double statement in 1 Corinthians 7:17a is not necessarily resolved as it can be understood as either two equivalent or parallel statements. Paul requires that a person

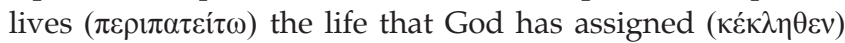

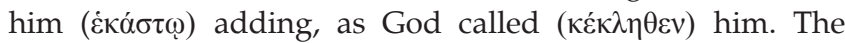
riddle of 1 Corinthians 7:17 can be resolved by appealing to 1 Corinthians 7:20 and a claim that the two statements, thus, are not identical, and that the second part relates to God's call which is received in specific social locations (the first part). This is a reasonable explanation but it does not remove all the ambiguity and tension from the text. ${ }^{29}$ Such ambiguity is, in fact, exacerbated by Paul's less than clear account of the implications of God's calling for the Corinthians to remain in their existing social locations (cf. Braxton 2000:48).

\section{$\pi \varepsilon \rho \iota \pi \alpha \tau \varepsilon \tilde{\imath} v / \mu \varepsilon v \varepsilon \tilde{\tau} v$ in the allotted life}

In 1 Corinthians 7:17, 20 and 24 Paul's appeal to the Corinthians to live or remain as they were, therefore, appears to have concerned their membership in the ekklesia, rather than to serve as a reference to social status in a general sense. A change of status was neither a precondition for the call from God nor a consequence of it, as much as Paul's appeal to the call of God was not an attempt to argue for the maintenance of the status quo (Braxton 2000:50-53). The emphasis on living out the calling of God is supported by the literary make-up of 1 Corinthians 7:17-24, that suggests careful attention to detail. The general call to serve the Lord (1 Cor 7:17), or to remain in God (1 Cor 7:24) wherever people find themselves in life, form an inclusio. ${ }^{30}$ Dealing with the distinction between people based on circumcision (1 Cor 7:18-19) ${ }^{31}$ or slavery (1 Cor 7:21-22), these two sections are both concluded with the call to remain ( $\mu \varepsilon v \varepsilon \dot{\tau} \omega, 1$ Cor 7:20; 1 Cor 7:24) in the calling in which they were called. ${ }^{32}$ Ethnic

29.The ambiguity of Paul's language emerges early in 1 Corinthians, when, in the first four chapters he encouraged unity amongst the Corinthian followers of Jesus by utilising an apocalyptic framework. Paul placed another world in opposition to the world of Graeco-Roman rhetoric and status, which was accompanied by upperclass ideology. Paul's world of apocalyptic reality proclaimed in the gospel of Christ class ideology. Paul's world of apocalyptic reality proclaimed in the gospel of Christ had its own alternative system of values and status attribution. In one sense the
apocalyptic world picked up on the conventional values of the time, but in another apocalyptic world picked up on the conventional values of the time, but in another
sense it counteracted and subverted those values (Martin 1995:57). Those whose arguments are aimed at defending Paul's liberative stance, are fond of citing bishops from the ranks of slaves such as Onesimus of Ephesus, Pius I of Rome, and Callixtus of Rome (cf. Payne 2009).

30.This argument is not only a matter of appealing structure, but is carefully formatted for maximum effect, for a diatribe structure in 1 Corinthians 7:21-22 (cf. Deming 1995:130-137).

31.Paul generally insisted that non-Jews remain non-Jews with regard to ritual and cultural behaviour (Runesson 2008:77)

32.The verses on slavery largely follow the pattern of the verses on circumcision, and 1 Corinthians 7:23 adds the further warning to the Corinthians not to become slaves of men because they are already slaves of God $(\tau \mu \eta \tilde{\zeta} \varsigma \dot{\eta} \gamma o \rho \alpha ́ \sigma \theta \eta \tau \varepsilon$, 'you were bought with a price'; cf. 1 Cor 6:20). 
distinctions are not affirmed here, nor is slavery commended, additionally nor is the calling of God seen as disruptive to these social situations, unlike what Paul appears to suggest elsewhere.

It is difficult to deny the intertextual links between 1 Corinthians 7 and Galatians 3:2833 without requiring or assuming some form of literary dependency. It is noteworthy though that 1 Corinthians 7:1-16 is all about sex and gender matters, in different configurations (marriage, celibacy, widowhood, single state), with the focus in 1 Corinthians 7:17-24 shifting to matters concerning the Jew and Gentiledistinction (1 Cor 7:18-19) and to slavery (1 Cor 7:21-23), before returning to the issue of celibacy and marital relationships in 1 Corinthians 7:25-40. ${ }^{34}$ Notwithstanding the danger of romanticised readings (cf. Punt 2010:140-166), Galatians 3:28 appears to contemplate, even if momentarily and in a cultic setting, the absolving of identities based on gender or sex, and ethnic and social status in Christ. ${ }^{35}$ However, 1 Corinthians 7:17-24 not only assume but even call for the maintenance of such social standings, even if they insist upon their irrelevance for the call of God. In fact, the concessions characterising 1 Corinthians 7:1-16 and 1 Corinthians 7:25-40 serve the immediate purpose of maintaining sex and gender divisions and structures built upon them.

Some scholars insist that Paul addressed all three issues of gender and sex, race and class together in order to avoid any simplistic handling of these matters. This is because:

crosscurrents and complexities prohibit over easy or overhasty 'solutions' to a pastoral and a moral theology that applies the gospel and liberation to a series of differing and changing contexts in the real world. (Thiselton 2000:545 agreeing with Bartchy, Cartlidge and Deming)

But this comment does not explain the differences in approach to gender and sex concerns on the one hand, and ethnic and social status concerns on the other hand. According to Braxton (2000):

[T] he force of the argument [of 1 Cor 7:17-24] may be to enjoin the Corinthians to remain as they are. Since, in the divine scheme, people have different gifts, acceptable concessions are suggested by Paul. (p. 15)

In short, 1 Corinthians 7 , and also verses $17-24$ are cast in ambiguity.

33.Galatians 3:28 has over many decades evoked much discussion amongst scholars, who see the text and Paul in general as a model for harmonious, multicultura communities, such as Barclay (1996:197-214). Others have argued that Paul's rhetoric relied on ethnicity rather than trying to obliterate it, and that his rhetoric relied on ethnicity rather than trying to obliterate it, and that his
concept of ethnicity was not static and monolithic, but flexible and complex, as concept of ethnicity was not static and monolithic, but flexible and complex, as
he differentiated between gentiles and Jews in Christ, and those who were not in he differentiated between gentiles and Jews in Christ, and those who were not in
Christ. For further discussion of the link between Galatians 3:28 and 1 Corinthians 7:17-24, cf. Braxton (2000:54-56), and on Galatians 3:28 cf. Punt (2010:140-166). For another intertext, cf. also 1 Corinthians 12:13.

34.Braxton makes the point that either clarity about the meaning of 1 Corinthians 7:17-24 or the meaning of the remainder of the chapter could have assisted in clarifying the other. However, as it stands, 1 Corinthians 7 in its parts and as a whole is shrouded in some ambiguity as far as meaning is concerned (Braxton 2000:7-67).

35.According to Braxton, Paul's sentiments in Galatians 3:28 are echoed here in 1 Corinthians 7:17-24 because he believed that 'in light of one's entrance into the eschatological community via God's call and the believer's baptism, certain social identity markers lose their importance or at least become relatively less important with respect to one's identity in Christ' (Braxton 2000:55).
One of the short but crucial instructions of Paul is $\mu \tilde{\alpha} \lambda \lambda$ ov $\chi \rho \tilde{\sigma} \sigma \alpha 1$ in 1 Corinthians 7:21, and its interpretation has in the past led to a wide variety of suggested options, the repeating of which, in this article, space does not allow. ${ }^{36}$ Suffice it to note that $\mu \tilde{\alpha} \lambda \lambda$ ov $\chi \rho \tilde{\eta} \sigma \alpha 1$ cannot be read or understood in isolation, and certainly is not to be disconnected from the first part of

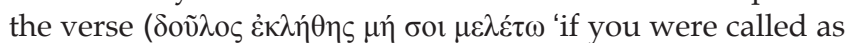
a slave, do not worry about it'). A reasonable conclusion is that Paul's use of $\mu \tilde{\alpha} \lambda \lambda$ ov $\chi \rho \tilde{\eta} \sigma \alpha \iota$ was deliberately ambiguous, and meant to suggest that concern about social status and position did not match up with giving expression to living according to God's calling. What would the implications have been in the first century, and what are contemporary readers to make of it in the 21st century? Such questions are important when on the one hand Paul is perceived not to have been a quietist intent on preserving the status quo but rather consciously and constantly challenging it. On the other hand Paul appears to have strived to establish his authority in the Corinthian community with its different groups and aspiring leaders?

Ambiguity is maintained throughout 1 Corinthians 7 and 1 Corintians 7:17-24 in particular (Braxton 2000; following Wire 1990:72). The notions in 1 Corinthians 7:22 are paradoxical, as this verse holds that being called in Christ, whilst a slave, changes such a person into a freed person belonging to the Lord, whilst, called in Christ as a free person changes free status into being a slave of Christ. The status of a freed person, in any case, hovered between truly and really free and enslavement, given the indissoluble bond between the former owner and the freed slave, perpetuated through the uneven relationship built upon the patronage system of the day. Given the careful literary construction of the text, it can be concluded that the ambiguity in 1 Corinthians 7 , including 1 Corinthians 7:17-24, is deliberate as it invited engagement and interpretation (Braxton 2000:271-273; cf. Kim 2008:58). The positive message of remaining with God (1 Cor 7:24) thus not only retains ambiguity as an 'intrinsic feature of the text'. In connection with 1 Corinthians 7:22, being called, 'in the Lord' is emphasis on a ministry of justice, and, at the same time, creates the possibility of challenging slavery (Braxton 2000:220-234). Indeed 'remaining with God' (1 Cor 7:24) is not a passive mode of doing nothing, but it can be understood positively. The Corinthians should stay with God's initiative and God's power that passes beyond human ideology and power. In this way, Paul can be read as challenging social conservatism and nullifying human constructions of power. 'Remain with God' can be read as an injunction to focus on God's initiative (Kim 2008:58).

The ambiguity of 1 Corinthians 7 is operative on a larger scale as well, as becomes evident when this chapter is read as part of the letter as a whole. In fact, the ambiguity can be traced to the author and his claims to power.

\section{Ambiguity amidst claims to power}

A clear and often cited formulation of the insistence on self-renunciation, the claim to disinvest from what accrues 36. Much literature is available on the topic, and recently a brief but accessible summary was provided by Thiselton (2000:553-559; 562-565). 
to the self and what reasonably can be claimed, is found in

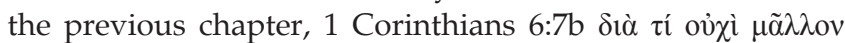

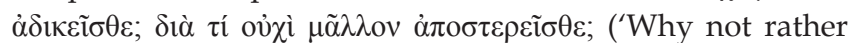
suffer wrong? Why not rather be defrauded?' RSV). Whilst in this context Paul discouraged law-suits amongst fellow believers, with both his telltale enthusiasm and sarcasm, castigating the Corinthians for 'wronging and defrauding...

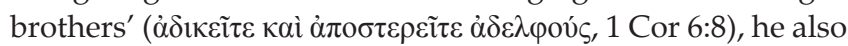
reproached them for their unwillingness to suffer wrong. ${ }^{37}$ In chapter 7, however, apart from promoting a celibate lifestyle where possible, self-renunciation does not seem to be the nature of Paul's appeals in 1 Corinthians 7, regardless of whether or not eschatology or social inequity formed the theological backdrop for Paul's letter.

As mentioned earlier, in the past, the eschatological edge in Corinthians was made into an interpretative grid for reading the letter. This suggests that tensions and questions in the community can be explained through an investigation of the distance between Paul's expectation of an imminent end, as opposed to the Corinthian community's realised eschatology. But the theological fault line in the PaulCorinthians relationship was probably situated in the disparate, unequal social standing of the community members, and Paul's deliberate attempts, not only to address the clashing values and social positions of the community members, but also to position himself in a particular way (cf. Martin 1990:142; 1995). Paul's tentative approach to both the wealthy and the poor in the community probably affected his handling of slavery. Slavery in the 1st century could not be disconnected from the structural, social system and complex set of convictions regarding hierarchical notions of human beings accompanied by ideas about exercising power and related expectations of submission, corporeal availability for sexual purposes, and punishment. This, at least, raises the question, why was Paul not at equally great pains to qualify and nuance his argument when it came to slavery, as he was with his instructions to various versions of married, unmarried and previously married people ${ }^{38}$ Although there is much ambiguity in 1 Corinthians 7 on many levels, and these are even freely indicated by Paul in terms of agency, why is such ambiguity present in 1 Corinthians 7:21-23 in particular, again, particularly given his distinctions between a multitude of different marital contexts?

Slavery in the 1st century may not have entailed a lifesentence of enslavement, because both informal and formal manumission was the order of the day. However, his letters provide no indication that Paul experienced slavery as a socio-political concern, in the way that he understood the inclusion of Gentiles in a faith or convictional system, derived from and adhering to its Jewish origins. In the case of the latter, he was willing to formulate different paradigms of understanding (such as a different theological notion, with

37.Similar sentiments were expressed in Plato's Gorgias 509C, and, thus, hasty conclusions about the New Testament's supposedly either superior or idiosyncratic moral code should be avoided (cf. Orr \& Walther 1976:195).

38.This is notable given, especially, Paul's concern with the avoidance of porneia in 1 Corinthians 5 and 1 Corinthians 7 , his claims about the link between bodies, sex and on the one hand pollution (1 Cor 5:16) and on the other hand sanctification (1 Cor 7:14,16), and the sexual availability of slaves to their owners.
God embodied in crucified, corporeal form) and systems of praxis (such as those beyond sacrificial notions, even beyond legal requirements with potential legalistic, static tendencies).

On the one hand, 1 Corinthians 7:17-24, like other Pauline texts, could be understood in terms of his belief about the relativisation of all things in Christ (Campbell 2008:89-93). On the other hand, in this text Paul is caught up in identity and power issues, and the flickering of emancipatory light happens amidst an all too human response. Thus, Paul's claims to authority abound in 1 Corinthians $7 .{ }^{39}$ He explicitly refers to his perception of speaking on behalf of Christ, regarding the position of unmarried people, because he

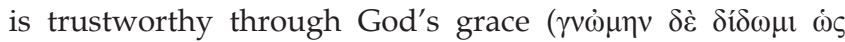

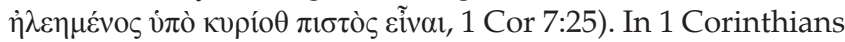

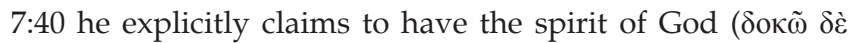

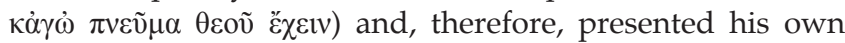

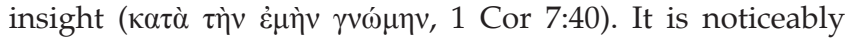
apparent from the beginning of the chapter that Paul assumes a knowledgeable position, and responds to questions

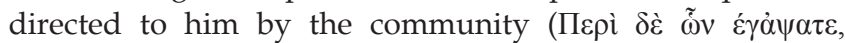
1 Cor 7:1). In 1 Corinthians 7:17 Paul assumes a position of issuing instructions $(\delta 1 \alpha \tau \alpha \dot{\sigma \sigma \sigma o} \mu \alpha)$, adding these to all the

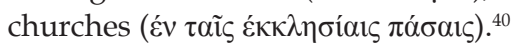

This agrees with the notion that 1 Corinthians 7 is deliberately steeped in ambiguity. However, unlike scholars who seek the resolution of ambiguity in Paul's well-meaning intentions (e.g. Thiselton 2000) or in Paul's sincere inability to conclude on matters, because of his genuine incapacity to do so (e.g. Braxton 2000:234), 1 Corinthians 7 with its ambiguity is also an attempt by Paul to establish his control and authority in a fluid, liminal context.

\section{Conclusion}

\section{Corinthians 7:17-24 for South African believers}

The ambiguous and relativising sentiments of 1 Corinthians 7:17-24 can neither be appropriated with simplistic appeals, nor be set aside with claims to a different context or ancient perspectives on humans and society. To the contrary, it is the metropolitan, 'yuppie' context of 1st century Corinth and a text set amidst and brimming with liminal perspectives, that provides an interesting inter(con)text for the vibrant, fast-evolving new South Africa, with its many dangers and opportunities, excitement and despair, celebrations of life and desperate miseries. It is the new South Africa that illustrates both the aptness as well as the obscurity of a claim such as the following:

One practical upshot of Paul's reply to Corinth is to establish the principle that neither freedom in the new creation nor obedient

39.Apart from these, other indications of power and authority are the references to àvó $\gamma \kappa \eta$ in 1 Corinthians 7:26 and also in 1 Corinthians 7:37 (translated with distress or necessity) and the frequent references to the control of passions and desire (1 Cor 7:2, 4-5, 9, 35, 36, 37). Some scholars argue that Paul deliberately went byon that 1 Corinthians 7:11 presents alternatives or exceptions to Jesus' teaching.

40. Contemporary interpreting communities need 'to choose the moment' in which to interpret texts, choosing whether or not to align themselves with an authoritarian role claimed by Paul or that of dependency required of the communities addressed. They also need to decide whether or not the particular attitude accompanying the role is appropriate today (cf. Polaski 2005:80-81). 
response to divine call can be compromised by the constraints of a person's circumstantial situation or status in everyday life. (Thiselton 2000:545; emphasis in original)

A crucial factor to a contextual interpretation of 1 Corinthians 7:17-24 is how notions, such as freedom and obedience, as well as social circumstances and divine calling are understood, and the scope and implications of such notions.

Paul's insistence on separating out a call from a social situation, and distinguishing God, who calls people and the social location in which people find themselves, is important in South Africa for past and present reasons. Whilst previous privilege, whether or not it was racial, political, economic or social, was grounded in an appeal to divine providence bestowed on the White rulers. A worrying current danger is a prosperity oriented faith (in Christian churches or otherwise) which equates God's calling with wealth and privilege. But, also the ambiguity of 1 Corinthians 7:17-24 lives on, however, in its appropriation in South Africa today. On the one hand, the primary importance of the calling of God, without invoking notions of providence, which were historically so harmful in the South African context, emphasises the initiative of God towards people without consideration of their contested identities or liminal position on the one hand, and without requiring of Christ followers to take leave of their initiatives and designs. But on the other hand, identity and liminality are not theoretical constellations only, but configure people's real, flesh-and-blood lives. Indeed marginality through race, sex or gender and social status are all too real in South Africa today. ${ }^{41}$

A major concern regarding the moral fibre of contemporary South African society is the question about authority, and moral authority in particular. With many communities of faith dented by erstwhile support for apartheid and with the realisation about lingering racist and even stronger patriarchal and homophobic attitudes, to name a few, moral leadership has become problematic. ${ }^{42}$ On the one hand, disavowing a conservative or quietist Paul, bent on perpetuating the status quo and affirming a subversive tendency in Paul's challenge to the perceived natural and social orders of the day, creates interesting interpretive possibilities. On the other hand, awareness of Paul's usurpation of power and authority, issuing instructions and at times confusing commands, triggers the realisation that Paul's socially challenging concerns, in an ironic way, rely upon a show of support for him, that buy into his understanding, his evaluation and his programme.

41.The "ideology of the dominant culture' assumes and often claims universality, seeing diversity as a problem and, therefore, as something to be overcome, which can be accomplished though negating or isolating and bracketing diversity. Because of its assumed or claimed universal status for its own context, the dominant culture bestows privileged authority on its own readings (Vena 2000:104).

42.A situation further complicated by the current presidency's call for mora rebuilding of the country amidst the president's alleged implication in corruption, his extra of the country anidst the president's alleged implication in corruption, interfaith La in ruling party and presidency whilst they ignore existing structures, such as the SA Council of Churches (not to mention structures of other faith communities), which incidentally, was quite prominent in the anti-apartheid struggle.

\section{Acknowledgement Competing interests}

The author declares that he has no financial or personal relationship(s) which may have inappropriately influenced him in writing this paper.

\section{References}

Barclay, J.M.G., 1996, " "Neither Jew nor Greek": Multiculturalism and the New Perspective on Paul', in M.G. Brett (ed.), Ethnicity and the Bible, vol. 19, pp. 197214, Biblical Interpretation Series, E.J. Brill, Leiden.

Bartchy, S.S., 1973, M国入入ov $\chi \rho[$ ? $\sigma \alpha$. First-Century Slavery and the Interpretation of 1 Cor 7:21, Scholars, Missoula.

Braxton, B.R., 2000, The Tyranny of Resolution: 1 Corinthians 7:17-24, SBL Dissertation Series, vol. 181, SBL, Atlanta.

Brett, M.G., 1998, 'Locating Readers: A Response to Frank Moloney', Pacifica 11(3), 303-315.

Briggs, S., 2000, 'Paul on Bondage and Freedom in Imperial Roman Society', in Pau and Politics. Ekklesia, Israel, Imperium, Interpretation. Essays in Honor of Krister Stendahl, in R.A. Horsley (ed.), pp. 110-23, Trinity Press International, Harrisville.

Buell, D.K., 2001, 'Rethinking the Relevance of Race for Early Christian Self-Definition', Harvard Theological Review 94(4), 449-476.

Campbell, W.S., 2008, Paul and the Creation of Christian Identity, T \& T Clark Biblical Studies, T \& T Clark, London.

Dawes, G.W., 1990 ' "But If You Can Gain Your Freedom” (1 Corinthians 7:17-24)', The Catholic Biblical Quarterly 52, 681-697.

Deming, W., 1995, 'A Diatribe Pattern in 1 Cor. 7:21-22: A New Perspective on Paul's Directions to Slaves', Novum Testamentum 37(2), 130-137. http://dx.doi. org $/ 10.1163 / 1568536952662781$

Elliott, N., 1994, Liberating Paul. The Justice of God and the Politics of the Apostle, The Bible \& Liberation, vol. 6, Orbis, Maryknoll.

Elliott, N., 2004, 'The Apostle Paul's Self-Presentation as Anti-Imperial Performance', In R.A. Horsley (ed.), Paul and the Roman Imperial Order, pp. 67-88, Trinity Press International, Harrisville.

Hollingshead, J.R., 1998, The Household of Caesar and the Body of Christ. A Political Interpretation of the Letters from Paul, University Press of America, Lanham.

Horsley, R.A., 1998, 1 Corinthians, Abingdon New Testament Commentaries, Abingdon, Nashville.

Keener, C.S., 1991, And Marries Another: Divorce and Remarriage in the New Testament, Hendrickson, Peabody.

Kelley, S., 2002, Racializing Jesus. Race, Ideology and the Formation of Modern Biblical Scholarship, Biblical Limits, Routledge, London \& New York.

Kim, Y.S., 2008, Christ's Body in Corinth. The Politics of a Metaphor, Paul in Critical Contexts Series, Fortress, Minneapolis.

Martin, D.B., 1990, Slavery as Salvation. The Metaphor of Slavery in Pauline Christianity, Yale University Press, New Haven.

Martin, D.B., 1995, The Corinthian Body, Yale University Press, New Haven and London.

Meeks, W.A, 1983, The First Urban Christians. The Social World of the Apostle Paul, Yale University Press, New Haven and London.

Ngugi wa Thiongo, 1986, Decolonising the Mind: The Politics of Language in African Literature, James Curry, London.

Orr, W.F. \& Walther, J.A., 1976, 1 Corinthians. A New Trans/ation. Introduction with a Study of the Life of Paul, Notes, and Commentary, The Anchor Bible, vol. 32, Doubleday, New York.

Osiek, C., 2005, 'Family Matters', in R.A. Horsley (ed.), Christian Origins, pp. 201-220, A people's history of Christianity, vol. 1, Fortress, Minneapolis.

Patterson, O., 1982, Slavery and Social Death: A Comparative Study, Harvard University Press, Cambridge, MA.

Payne, P.B., 2009, 'Twelve Reasons to Understand 1 Corinthians 7:21-23 as a Call to Freedom', viewed 15 June 2010, from http://www.pbpayne.com/wp-admin/1 Cor_7_21_escape_slavery.pdf

Polaski, S.H., 2005, A Feminist Introduction to Paul, Chalice, St Louis.

Punt, J., 2007, 'Popularising the prophet Isaiah in parliament: The Bible in postapartheid, South African public discourse', Religion \& Theology 14(2), 206-223. http://dx.doi.org/10.1163/157430107X241285

Punt, J., 2009, 'Post-apartheid racism in South Africa. The Bible, social identity and stereotyping', Religion \& Theology 16(3-4), 246-272. http://dx.doi.org/10.1163/ 102308009X12561890523672

Punt, J., 2010, 'Paul, Power and Philemon. "Knowing Your Place"': A Postcolonial Reading, in F. Tolmie (ed.), Philemon in Perspective. Interpreting a Pauline Letter 223-250, BZnW, vol. 169, Walter De Gruyter, Berlin \& New York.

Runesson, A, 2008 'Inventing Christian Identity: Paul, Ignatius, and Theodosius I', in B. Holmberg (ed.), Exploring Early Christian Identity, pp. 59-92, Wissenschaftliche Untersuchungen zum Neuen Testament, vol. 226, Mohr Siebeck, Tübingen. 
Schweitzer, A., 1968, The Mysticism of Paul the Apostle, 2nd edn., transl. W. Montgomery, MacMillan, New York.

Sport24, 2010, 'Ox killed to bless stadiums', viewed 26 May 2010, from http://www. sport24.co.za/WorldCup/NationalNews/Ox-killed

Theissen, G., 1983, The Social Setting of Pauline Christianity: Essays on Corinth, transl. J. Schütz, Fortress, Philadelphia.

Thiselton, A.C., 2000, The First Epistle to the Corinthians. A Commentary on the Greek Text, The New International Greek Testament Commentary, Eerdmans, Paternoster, Grand Rapids, Carlisle.
Thiselton, A.C., 2006, First Corinthians. A Shorter Exegetical and Pastoral Commentary, Eerdmans, Grand Rapids, Cambridge.

Vena, O.D., 2000, 'My Hermeneutical Journey and Daily Journey into Hermeneutics: Meaning-making and Biblical Interpretation in the North American Diaspora', In F.F. (ed.), Segovia Interpreting beyond Borders, pp. 84-106, The Bible and Postcolonialism, vol. 3, Sheffield Academic Press, Sheffield.

Wire, A.C., 1990, The Corinthian Women Prophets. A Reconstruction Through Paul's Rhetoric, Fortress, Minneapolis. 